UDC 004.9:621.74

A.B. Kungurtsev ${ }^{1}, \mathrm{PhD}$, Prof.,

Yu.I. Senkevich ${ }^{2}$,

H.O. Zinovatnaya ${ }^{1}$,

N.O. Novikova ${ }^{3}$

${ }^{1}$ Odessa National Polytechnic University, 1 Shevchenko Ave., 65044 Odessa, Ukraine; e-mail: abkun@te.net.ua

${ }^{2}$ Scientific Research Institute of Special Casting Methods, 2 Khimichna Str., 65031 Odessa, Ukraine

${ }^{3}$ Odessa National Maritime University, 34 Mechnykova Str., 65029 Odessa, Ukraine

\title{
THE ALGORITHMS FOR AUTOMATED CALCULATION OF THE FURNACE CHARGE IN SMELTING
}

\author{
AND REFINING METAL
}

О.Б. Кунгуриев, Ю.І. Сенкевич, Г.О. Зіноватна, Н.О. Новікова. Алгоритми автоматизованого розрахунку шихти при плавленні і доведенні металу. Отримання вихідного рідкого металу з мінімальними відхиленнями від регламентованого хімічного складу є однією $з$ головних умов виготовлення високоякісних виливків з заданим комплексом фізико-механічних і експлуатаційних властивостей. Важливим фактором $€$ також оптимізація складу шихти з метою зниження витрат виробництва. Комплексні програмні рішення для автоматизації управління процесом плавки не користуються попитом малих і середніх підприємств через високу вартість і складність. Мета: Метою роботи є автоматизація розрахунків шихти для отримання розплаву із заданим комплексом фізико-механічних і експлуатаційних властивостей шляхом розробки $\mathrm{i}$ реалізації відповідних алгоритмів, шо дозволяють отримувати мінімальний за вартістю склад шихти з урахуванням обмежень за компонентами. Mamepiaли i методи: Запропоновано методику розрахунку маси компонентів для отримання розплаву заданого хімічного складу. Модель враховує взаємозв'язки між необхідним складом розплаву у вигляді множини хімічних елементів і множини компонентів; в свою чергу, кожний компонент описується як множина хімічних елементів. Результати: Описано алгоритми перевірки коректності вихідних даних за діапазоном кількості компонентів і за хімічним складом, визначення вихідної множини компонентів 3 подальшим коригуванням для встановлення мінімальної сумарної вартості, алгоритм усунення надлишку хімічного елементу в розплаві. Запропонована методика дозволяє на початковому етапі розрахунку виявити недопустимі значення у вихідних даних. Алгоритми реалізовано у вигляді програмного продукту.

Ключові слова: шихта, розплав, автоматизований розрахунок.

A.B. Kungurtsev, Yu.I. Senkevich, H.O. Zinovatnava, N.O. Novikova. The algorithms for automated calculation of the charge in smelting and refining metal. The production of the initial liquid metal with minimal departures from the regulated chemical composition is one of the main conditions of the composition of the furnace charge to reduce production costs. The program complexes to automate the management of the entire melting process cannot be claimed by small and medium businesses because of the high cost, complexity and increased requirements for the qualification of personnel. Aim: The aim of the research is to automate the calculation of the furnace charge for obtaining a melt with a given set of physical, mechanical and operational properties by developing and implementing appropriate algorithms to obtain a minimum cost composition of the furnace charge, taking into account the limitations of the components. Material and Methods: Proposed method for calculating the mass of components for obtaining the melt of predetermined chemical composition using the model of initial and output data. The model takes into account the relationships between the required melt composition in the form of a multitude of chemical elements and a multitude of components, in turn the component is described as a set of chemical elements. Results: Algorithms for checking the correctness of the initial data on the range of the number of components and chemical composition, determining the output set of components with subsequent correction for determining the minimum total cost, an algorithm for eliminating the excess of the chemical element in the melt are described. The proposed method allows identifying at the initial stage of calculation the unacceptable values in the initial data. Algorithms are implemented in the form of a software product that can be used by small and medium business.

Keywords: furnace charge, melt, automated calculation.

Introduction. The production of the initial liquid metal with minimal departures from the regu-

DOI 10.15276/opu.1.51.2017.11

(C) 2017 The Authors. This is an open access article under the CC BY license (http://creativecommons.org/licenses/by/4.0/).

COMPUTER AND INFORMATION NETWORKS AND SYSTEMS. MANUFACTURING AUTOMATION 
lated chemical composition is one of the main conditions for the production of high-quality castings with predetermined physical, mechanical and operational properties. An important factor is also the optimization of the composition of the furnace charge to reduce production costs.

Currently, modern large-scale melting plants are equipped with perfect computer systems to automate the management of the entire melting process, incl. calculation of furnace charge (technological and economic) and refining the liquid metal to the predetermined chemical composition during the melting process. Manufacturers of large furnaces already at the design stage install the program complexes for induction furnaces to calculate and optimize the composition of the furnace charge components. For example, Otto Junker medium-frequency furnaces are equipped with JOKS furnace control system, which provides continuous monitoring and automatic control of all technological operations in the furnace during the melting cycle [1,2]. ABP Induction Systems GmbH, the largest and oldest manufacturer of such equipment, EGES, etc., equip its induction furnaces with similar systems [3, 4]. Industry Siemens offers furnace control systems based on modern automation and information technology using dynamic process models [5]. There are also known scientific studies aimed at the integrated automation of large industries [6].

Unfortunately, the program complexes mentioned above and the corresponding equipment cannot be claimed by small and medium businesses because of the high cost, complexity and increased requirements for the qualification of personnel.

There are software solutions for the calculation of the furnace charge, providing its minimum cost. Most often, linear programming methods are used for this [7], which do not allow evaluating the reasons for the absence of a solution and offering a rather complex process of preparing the initial data. Proposed software solutions usually do not take into account the available amount of furnace charge components [8]. Most programs solve rather specific problems of obtaining specific alloys [9...11]. In all cases, there is no preliminary analysis of the possibility of obtaining the predetermined chemical composition of the melt at given initial data, the possibility of refining the melt, i.e. selection and calculation of the number of components for adjusting the quality of metal based on rapid analysis.

The aim of the research is to automate the calculation of the furnace charge for obtaining a melt with a given set of physical, mechanical and operational properties by developing and implementing appropriate algorithms to obtain a minimum cost composition of the furnace charge, taking into account the limitations of the components.

The final software product should be cost affordable and easy to use.

The software being developed should solve the following tasks:

- Accounting the receipt and consumption of components of the furnace charge and determine availability of the components;

- Preliminary analysis of the initial data in terms of identifying errors and the possibility of obtaining a solution;

- Finding the chemical composition of the furnace charge that is optimal for technological requirements and cost;

- Adjusting the chemical composition of the melt according to the results of its rapid analysis;

- Storing and structuring the data on smelting for later analysis.

Materials and Methods. It is necessary to obtain a melt with a predetermined mass mass $M$ and chemical composition. It is allowed to increase the mass of the melt by PercM (or $d m$ fractions, $d m=$ PercM/100). To obtain the melt, it is required to collect the furnace charge from the available component inventory. Some components are required. For them, indicate the minimum and maximum percentage (fraction) in the furnace charge. Other components are needed to adjust the chemical composition of the melt. For them, fractions are not indicated. Each component consists of a base and additional chemical elements. The amount of each element in a component is characterized by its fraction. During the preparation of the melt, the amount of the base and elements of the component decreases. This should be taken into account using the recovery rate (given in percentages) for the base and other constituent elements. Also, the recovery rate of a certain element, which is included in different components, can be different. Each component has a specific cost per unit of mass (kg). 
It is necessary to form a furnace charge that provides the predetermined mass and chemical composition of the melt and has a minimum cost. The following expression allows us to formalize the problem

$$
\text { CostCh }=\sum_{i=1}^{n c c} \operatorname{Cost} \text { CompMass }_{i} \rightarrow \min ,
$$

where CostCh - cost of the furnace charge, necessary for obtaining a melt of predetermined chemical composition;

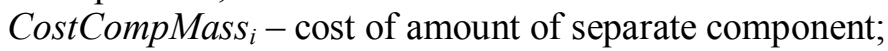

$n c c$ - number of different components.

It is proposed to solve the problem by the gradient method of steepest descent $[12 \ldots 14]$. For this, the following premises are available:

- we can give an informed decision to choose the initial values of the function CostCh $=f\left(\operatorname{Cost} \operatorname{CompM}_{1}, \operatorname{Cost}_{\text {CompM }}, \ldots\right.$, Cost $\left.\operatorname{Comp} M_{n c c}\right)$;

- we can give an analytical solution for choosing the coordinates of motion;

- we can give an informed decision to select the step of changing the coordinates of the current point;

- in some cases, we can determine the reasons for the absence of a solution.

Data presentation. The furnace charge is defined as the set of $M E M$ elements specifying its chemical composition and the many $M C C$ components providing the fixed chemical composition, $M E M \subseteq M E, M C C \subseteq M C$, where $M E$ is the set of all possible elements, $M C$ is the set of all possible components, $n c=|M C|, n e=|M E|$. the form

Each component consists of the base and the regulated elements. We represent the component in

$$
\text { Comp }=<\text { nameComp, MCE, KadoptCM, CostComp, MassComp, Fabricator }>\text {, }
$$

where nameComp $\in M C$ - name of the component;

$M C E$ - set of elements that make up the component;

KadoptCM - recovery rate of the basis of the component;

CostComp - cost of $1 \mathrm{~kg}$ of the component;

Mass Comp - available amount of the component, kg;

Fabricator - information about the component manufacturer.

We represent the element of the component in the form

$$
\text { Elem }_{k}=<\text { nameE }_{k}, \text { de }_{i k}, \text { Kadopt }_{i k}>,
$$

where $n a m e E_{k} \in M E$ - name of the element (for example, to produce cast iron, this can be $C, S i, S$ ).

$d e_{i k}-k$-th element's fraction in the $i$-th component;

Kadopt $_{i k}$ - recovery rate of the $k$-th element in the $i$-th component .

The predetermined melt is defined as follows

$$
\text { Mailt }=<\text { name } M, \text { MEM, } \operatorname{mass} M, d m>,
$$

where nameM - name of the melt;

mass $M$ - required mass of the melt;

$M E M$ - set of elements that determine the chemical composition of the melt;

$d m$ - permissible increase in the mass of the melt.

The elements of the MEM set are defined as follows

$$
\text { Elem }_{j}=<\text { nameE }_{j}, d e_{j}>, j=\overline{1, n e c},
$$

where $d e_{j}-j$-th element's fraction in the melt Mailt;

nec $=|M E M|-$ number of different elements in the melt Mailt . 
To obtain the melt, it is required to calculate the furnace charge, which is determined by the components' set $M C C$ which necessary to obtain the predetermined chemical composition. Below is the expanded representation (1) of the component

$$
\begin{aligned}
& \text { Comp }_{i}=<\text { nameComp }_{i}, \text { MCE }_{i}, \text { KadoptCM }_{i}, L_{i}, H b_{i}, F l R q_{i}, \text { MassCompC }_{i} \text {, } \\
& \text { CostComp }_{i}, \text { MassComp }_{i}, \text { Fabricator }_{i}>, i=\overline{1, n c c} \text {, }
\end{aligned}
$$

where $L b_{i}$ - lower limit of the $i$-th component's amount in the melt Mailt (given in fractions of MassM);

$H b_{i}$ - upper limit of the $i$-th component's amount in the melt Mailt (given in fractions of MassM);

$F l R q_{i}$ - flag that determines whether a component is required in the melt; if yes, then $F l R q_{i}=1$, otherwise $-F l R q_{i}=0$;

Mass Comp $C_{i}$ - mass of the $i$-th component necessary for obtaining the melt Mailt ;

$n c c=|M C C|-$ number of different components in the melt Mailt .

The mass of the element nameE $E_{j}$ in the melt is determined from its fraction in the melt $\operatorname{mass} M E_{j}=\operatorname{mass} M \times d e_{j}$.

The amount of the required component nameComp $p_{i}$ in the melt is determined by its fraction

$$
H b_{i} \geq \frac{\operatorname{MassCompC}_{i}}{\operatorname{Mass} M} \geq L b_{i} .
$$

The mass of the $i$-th component, which must be taken to obtain the mass unit of the melt, taking into account the recovery of this component, is determined by the formula

$$
\operatorname{mass} \operatorname{Comp}_{i}=\frac{1-\sum_{k=1}^{n c e_{i}} d e_{i k}}{\operatorname{KadoptCM}_{i}}+\sum_{j=1}^{n c e_{j}} \frac{d e_{i k}}{K_{\text {adopt }} E_{i k}},
$$

where $n c e_{i}$ - number of elements in the $i$-th component.

We introduce the concept of the recovery rate of the component

$$
\operatorname{Kadopt}_{i}=\frac{1}{\operatorname{mass} C o m p C_{i}} .
$$

The cost of the furnace charge $\operatorname{Cos} t C h$ for obtaining the melt can be determined after determining the components from which the charge will be made.

Preliminary verification allows you to eliminate errors in the original data. The checks are arranged in order of increasing complexity of their implementation.

Algorithm 1. Checking the correctness of the ranges of the component set.

It is determined by the sum of the upper limits of required components' fractions

$$
S h=\sum_{i=1}^{n c}\left(H b_{i}, F l R q_{i}=1\right)
$$

If $S h<1$, then a set of a given mass of furnace charge is impossible (shortage).

It is determined by the sum of the lower limits of required components' fractions

$$
S l=\sum_{i=1}^{n c}\left(L b_{i}, F l R q_{i}=1\right) .
$$

If $S l>1$, then the set of a given mass of furnace charge is impossible (excess). 
If $M a s s M \times L_{i} \times \operatorname{KadoptC}_{i}>\operatorname{MassComp}_{i}, F l R q_{i}=1$ is at least for one required component, then this component cannot be used.

If Mass $M \times H b_{i} \times \operatorname{KadoptC}_{i}>$ MassComp $_{i}, F l R q_{i}=1$ is at least for one required component, then the upper limit of the mass of this component is unattainable. It may be necessary to set a lower upper limit value:

$$
H b_{i}=\frac{\operatorname{Mass} C o m p_{i}}{M a s s M \times \operatorname{KadoptC}_{i}} .
$$

Algorithm 2. Preliminary verification of data on the chemical composition.

1. Checking the absence of elements in components.

If there is an element name $E_{j} \notin M C E_{l} \wedge N a m e E_{j} \in M E M$ for all $l=\overline{1, n c}$, where $M C E_{l}$ - set of elements of the $\mathrm{Comp}_{l}$ component, $n c$ - number of all components (required and optional), then a set of furnace charge with the predetermined chemical composition is impossible.

2. Checking the excess of the mass fraction of elements in the required components.

If there is an element $n a m e E_{j} \in M E M \wedge d e_{i j}>d e_{j}$ for all $i=\overline{1, n c c}, F l R q_{i}=1$, then a set of furnace charge with the predetermined chemical composition is impossible.

3. Checking the melt chemical composition at minimum mass fractions.

The mass of the $i$-th required component of the furnace charge by the lower limit

$$
\text { mass Comp }_{i}=\text { massM } / \text { Kadopt }_{i} \times L b_{i} \text { for } i=\overline{1, n c c} \text {. }
$$

The mass of the $i$-th required component in the melt is determined

$$
\operatorname{mass} \operatorname{CompM}_{i}=\operatorname{mass} M \times L b_{i} \text { for } i=\overline{1, n c c} .
$$

The total mass of the components is determined

$$
\text { mass ChTemp }=\sum_{i}^{\text {ncc }} \text { massComp } \text {. }_{i}
$$

The mass of the melt is determined

$$
\text { massMTemp }=\sum_{i}^{n c c} \operatorname{mass}_{i} .
$$

Mass of the $j$-th element in the melt

$$
\operatorname{mass} E M_{j}=\operatorname{mass} M \times d_{j} \text { for } j=\overline{1, n e c} .
$$

The mass of the $j$-th element entering into all components of the melt

$$
\text { massETemp }_{j}=\sum_{i=1}^{n c c} \text { mass Comp }_{i} \times \operatorname{de}_{i j} \times \operatorname{Kadopt}_{i j} .
$$

If for some element massETemp ${ }_{j}>{\text { mass } M E_{j}}_{j}$, then the furnace charge set is impossible in terms of chemical composition (the mass content of the name $E_{j}$ in component's set $M C C$ is exceeded).

Algorithm 3. Checking the possibility of obtaining the required chemical composition of the furnace charge.

This algorithm does not take into account the cost of components. As the initial values, we take the masses of all the required components established on the lower limits. At each stage, the gradient is determined by the component with minimum mass content of chemical elements. The step of changing the amount of the component is determined by the largest mass of the component, which can be taken based on the mass of the melt, limitations on the component' fraction, and compliance with the predetermined chemical composition of the melt. 
Missing elements are introduced at the final stage of furnace charge formation by adding optional components.

1. The components are ranked according to the mass content of the elements relative to the melt. To do this, we introduce the concept of the ratio of the fractions of each element in the melt and the component

$$
\varepsilon d_{i j}=\frac{d e_{i j}}{d e_{j}} \times \text { Kadopt } E_{i j} .
$$

For each component the maximum value of the ratio $\varepsilon d \max _{i}$ is determined. A list of components ListComp arranged in ascending order $\varepsilon d \max _{i}$ is compiled. In the future, the component is determined by its index in the list ListComp .

The variable massMTemp determines the current mass of the melt, and the initial value massMTemp $=0$.

The variable massChTemp determines the current mass of the furnace charge, and the initial value massChTemp $=0$.

The component's position $p$ is set, and the initial value $p=1$.

2. The masses of all required components are determined (except Comp $p_{p}$ ) by the lower limit

and the corresponding melt mass

$$
\operatorname{massComp}_{i}=\left(\operatorname{mass} M / \text { Kadopt }_{i}\right) \times L b_{i} \text { for } i=\overline{1, n c c} \wedge i \neq p,
$$

$$
\operatorname{mass}_{i}=\operatorname{mass} M \times L b_{i} \text { for } i=\overline{1, n c c} \wedge i \neq p .
$$

The total mass of these components is determined

$$
\text { massChTemp }=\sum_{i}^{n c c} \text { massComp }, i \neq p,
$$

and the mass of the corresponding melt

$$
\text { massMTemp }=\sum_{i}^{n c c} \operatorname{mass}_{i}, i \neq p .
$$

3. The mass of the component $p$ by the upper limit is determined:

$$
\begin{gathered}
\text { massComp }_{p}=\left(\text { mass } M / \text { KadoptC }_{p}\right) \times H b_{p}, \\
\text { massChTemp }=\text { massChTemp }+ \text { mass Comp }_{p}, \\
\text { mass } M_{p}=\text { mass } M \times H b_{p}, \\
\text { massMTemp }=\text { massMTemp }+{\text { mass } M_{p} .}^{\text {mass }} .
\end{gathered}
$$

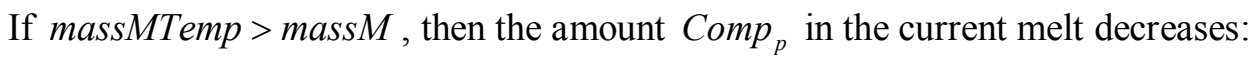

$$
\text { mass Comp }_{p}=\text { mass Comp }_{p}-(\text { massMTemp }- \text { massM }) / \text { KadoptC }_{p} .
$$

In this case massMTemp $=$ mass $M$.

4. The total mass of each element entering into all components of the current melt

$$
\text { massETemp }_{j}=\sum_{i=1}^{n c} \operatorname{massComp}_{i} \times d e_{i j} \times \operatorname{KadoptE}_{i j} .
$$

If for some element nameE ${ }_{j}$ its mass massETemp ${ }_{j}>\operatorname{mass}_{j}$, then the component nameComp $p_{i}$ with the minimal value $\varepsilon d \max _{i}$ of the element $n a m e E_{j}$ is determined. 
The excess mass of the element $n a m e E_{j}$ in the melt is determined

$$
\Delta=\operatorname{mass}_{j}-{\text { mass } E M_{j}} .
$$

The furnace charge composition is adjusted by decreasing the mass of the component nameComp $_{p}$ and increasing the mass of the component nameComp $p_{i}$ by a value $m$ that is determined from the condition for correcting the element:

$$
\Delta+m \times d e_{i j} \times \operatorname{Kadopt} E_{i j}=m \times d e_{p j} \times \operatorname{Kadopt} E_{p j} .
$$

Thus

$$
m=\frac{\Delta}{d e_{p j} \times \operatorname{Kadopt}_{p j}-d e_{i j} \times \operatorname{Kadopt}_{i j}} .
$$

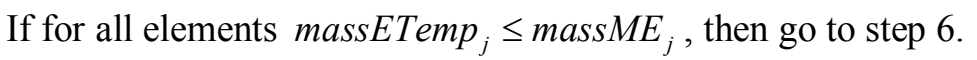

If $p \neq 1$ and for some element massETemp $p_{j}>{\operatorname{mass} M E_{j}}_{\text {, then }}$ go to step 5.

5. The mass of the component $\operatorname{Comp}_{p}$ decreases to a value providing a predetermined amount of the element nameE $_{j}$ in the melt.

For this purpose, the total mass of the furnace charge is corrected:

$$
\text { massChTemp }=\text { massChTemp }- \text { mass Comp }_{p} .
$$

The total mass of the melt is corrected:

$$
\text { massMTemp }=\text { massMTemp }-\operatorname{mass} M_{p} .
$$

The mass of the component is corrected:

$$
\text { massComp }_{p}=\text { massComp }_{p}-\left(\text { massETemp }_{j}-\text { mass ME }_{j}\right) / d e_{i j} \text {. }
$$

A new amount of melt corresponding to the component $p$ :

$$
\operatorname{mass}_{p}=\operatorname{massComp}_{p} / \mathrm{KadoptC}_{p} .
$$

The new current amount of melt is determined:

$$
\text { massMTemp }=\text { massMTemp }+ \text { mass }_{p} .
$$

The new current amount of furnace charge is determined:

$$
\text { mass ChTemp }=\text { massChTemp }+ \text { massComp }_{p} \text {. }
$$

Go to step 4.

$6 p=p+1$. If $p \leq n c c$, then go to step 3 .

If

$$
\text { Mass } M \leq \text { massMTemp } \leq \operatorname{mass} M \times(1+d m),
$$

then go to step 7, otherwise - go to step 9 .

7. Correction of the chemical composition of the furnace charge by the optional components.

For each element, its shortage is determined in massMTemp :

$$
\Delta_{j}=\operatorname{massME}_{j}-\text { massETemp }_{j} .
$$

The elements are ranked in order of decreasing their masses.

Optional components are ranked as follows. One group includes components with the same value $n c e_{i}=\left|M C E_{i}\right|$ (the amounts of different chemical elements in the component). Groups are ranked in ascending order $n c e_{i}$. Within one group, the components are ranked by increasing the ratio of the mass of the elements to the total mass of the component. 
Sequentially, for each element with a missing mass, an optional (corrective) component is determined, which ensures that the required mass of the element

$$
\operatorname{massCompD} D_{l}=\frac{\Delta_{j}}{d e_{l j} \times \operatorname{KadoptC}_{l}} .
$$

The total mass of the correcting components is determined

$$
\text { mass CompD }=\sum \operatorname{mass} C o m p D_{l} \text {. }
$$

The total mass of the added elements in the melt is determined

$$
\operatorname{mass} M D=\sum_{j=1}^{m} \Delta_{j} .
$$

The total mass of all components is determined

$$
\text { mass ChTemp }=\text { massChTemp }+ \text { massCompD, }
$$

and the current mass of the melt

$$
\text { massMTemp }=\text { massMTemp }+ \text { massMD . }
$$

If massMTemp $\leq$ mass $M \times(1+d m)$, then the components can provide the predetermined chemical composition of furnace charge. Go to step 9 .

8. A furnace charge composition is possible if increased $d m$.

9. The end of the algorithm.

Algorithm 4. Selection of components with a minimum total cost.

1. A list of required components ListComp 1 is formed in order of increasing cost. Each item of the list stores a number (index) in accordance with the previously compiled list ListComp. Thus, the component can be represented in the form

$$
<\operatorname{Comp}_{i}, r_{i}, s_{i}>\text {, }
$$

where $r_{i}$-component index in the list ListComp 1 ,

$s_{i}$ - component index in the list ListComp .

2. Algorithm 3 is applied, starting with step 2.

3. If the desired composition of the furnace charge is obtained, then the calculation ends. Otherwise, go to step 4.

4. The component $\operatorname{Comp}_{i}$ with the smallest index $s_{i}$ (for which the condition $s_{i} \neq r_{i}$ is satisfied) is determined.

If such component is found, then the positions of the components Comp $\mathrm{C}_{i}$ and $\mathrm{Comp}_{l}$ are exchanged $\left(r_{l}=r_{i}-1, s_{l}=s_{i}\right)$. If as a result of the permutation, all the elements of the list ListComp 1 have received indexes $r$ in ascending order, then the furnace charge composition obtained earlier on the basis of Algorithm 3 is taken as the result.

Otherwise, go to step 2.

The process ends when the desired mass is reached or all elements of the current melt are analyzed.

The results of express analysis can be represented as:

$$
\text { MailtA }=<\text { nameM },\left\{\text { Elem }_{j}\right\}>j=\overline{1, n e c},
$$

where ElemA $_{j}=<$ nameE $_{j}, \operatorname{def}_{j}>$, def $f_{j}$ actual fraction of the element nameE $E_{j}$ in the current melt.

The lack of chemical elements is eliminated by adding corrective components. This procedure does not require special analysis.

If an excess of chemical elements is found in the melt, the following algorithm is proposed. 
Algorithm 5. Elimination of excess of chemical element in the melt.

1. Determine the chemical element name $E_{j}$ for which the excess is greatest.

2. Determine the component nameComp $p_{i}$ containing the smallest amount of element nameE . $_{j}$.

3. Determine the mass of the melt $m 1$ which should be poured to adjust the chemical composition, based on the condition:

$$
\begin{gathered}
{\operatorname{mass} M \times d e f_{j}-}_{-} 1 \times \operatorname{def}_{j}+\frac{m 1}{\operatorname{KadoptCM}_{i}} \times \operatorname{de} e_{i j} \times \operatorname{Kadopt}_{i j}=\operatorname{mass} M \times d e_{j}, \\
m 1=\frac{\operatorname{mass} M \times\left(\operatorname{def}_{j}-d e_{j}\right)}{\operatorname{def}_{j}-\operatorname{de}_{i j} \times \operatorname{KadoptE}_{i j} / \operatorname{KadoptCM}_{i}} .
\end{gathered}
$$

4. The mass of the component to be added is determined

$$
\text { massComp }_{i}=m 1 / \mathrm{KadoptCM}_{i} \text {. }
$$

5. If there aren't excessive components in the melt, the process is completed. Otherwise, return to step 1.

Results. In accordance with the above algorithms, the program MixCh was created.

MixCh supports three user groups:

- "Enterprise Management"; privileges - reading and writing data on the availability of components in the warehouse, reading data on the conducted smelting;

- "Metallurgist"; privileges - reading and writing data on the composition of the furnace charge, calculation the furnace charge taking in account with available components;

- "Smelter"; privilege - reading data on the composition of the furnace charge.

The examples of MixCh program windows shown in Fig. 1...3.

The software product was tested for casting the iron mark VC 50-7 in the operating conditions of the "Aralit S.A." enterprise (Chisinau). The use of MixCh program ensured fast and qualitative calculation of the furnace charge, which allowed obtaining the metal with the required chemical composition.

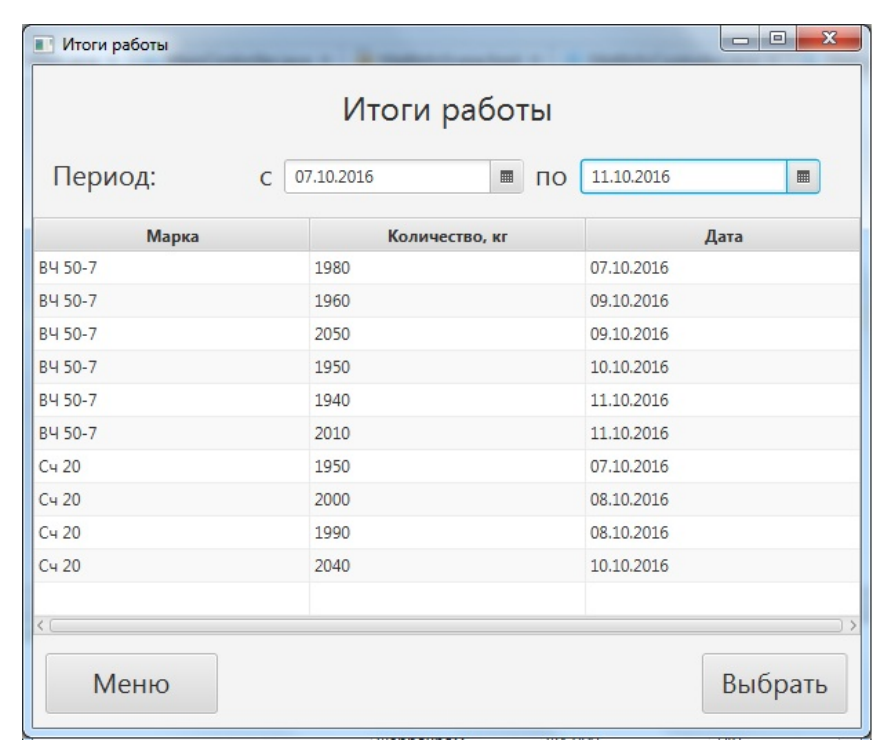

Fig. 1. Window with data on the conducted smelting (for "Enterprise Management" and "Metallurgist" groups)

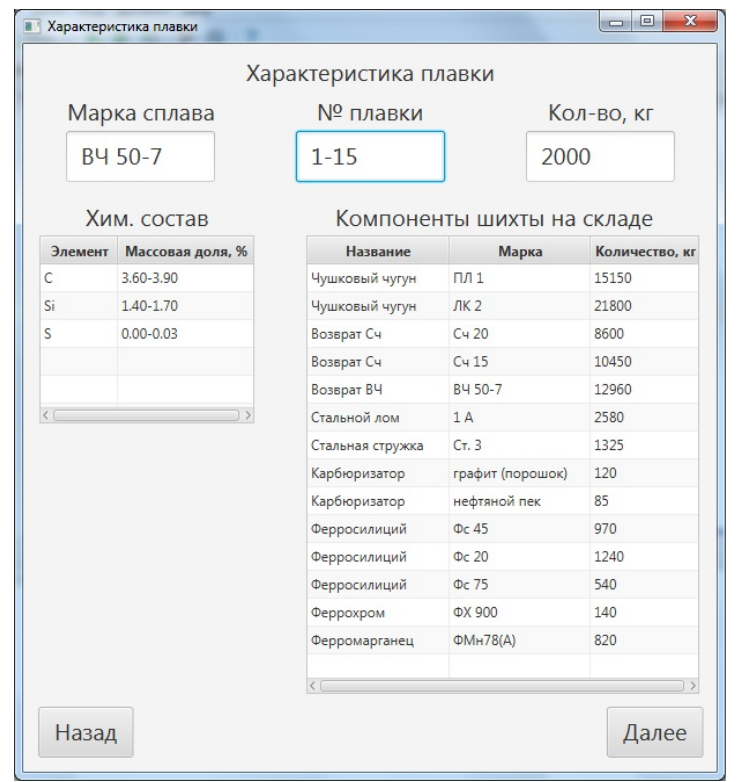

Fig. 2. Window for determining the chemical composition of the furnace charge (for "Metallurgist" group) 


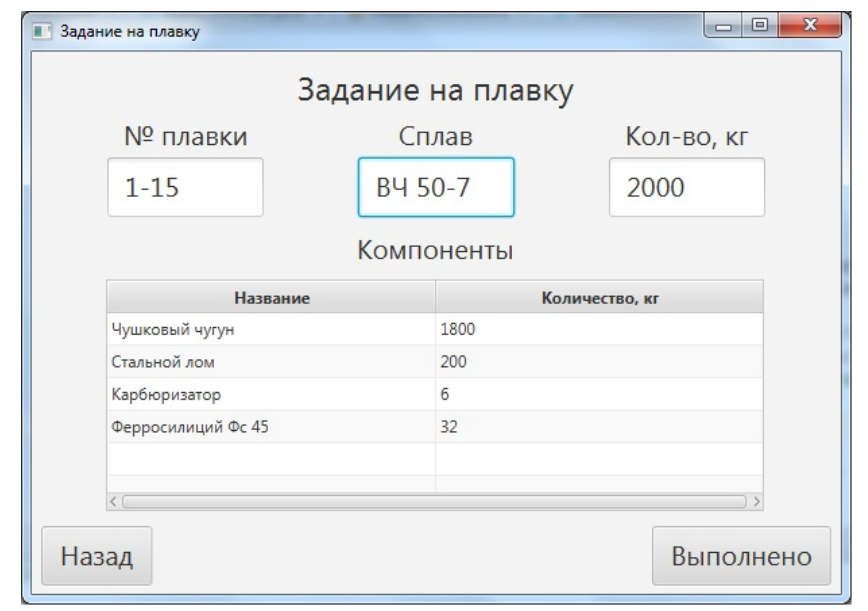

Fig. 3. Window for selecting melting and its components (for "Smelter" group)

Conclusions. The developed algorithms for automation of furnace charge calculation for obtaining a melt with the specified characteristics allow significantly reducing the time for task execution, providing error detection at the stage of task formation and allowing automating the recording of the availability and consumption of materials. The proposed software product is simple and understandable for users and is available for organizations with limited financial resources.

\section{Література}

1. Trauzeddel, D. Prozessorientierte Mittelfrequenzofentechnik / D. Trauzeddel // Giesserei Rundschau. 2014. - Jhg. 61, Heft 1/2. - S. 16-21.

2. Марукович, Е.И. Литейные сплавы и технологии / Е.И. Марукович, М.И. Карпенко. - Минск: Беларус. навука, 2012. -442 с.

3. Ertl, W. Melting of large steel casting parts in the induction furnace / W. Ertl, E. Dötsch // Heat Processing. - 2015. - Issue 2. - PP. 103-107.

4. Сезгин, Э. Эффективность технологий плавки в печах производства фирмы EGES / Э. Сезгин // Литье и металлургия. - 2010. - № 3. - С. 147-148.

5. Мизгир, А.Г. Современные системы автоматизации процессов плавки стали в индукционных и электродуговых печах / А.Г. Мизгир, Р.Е. Аладьев // Литье и металлургия. - 2012. - № 3(67). C. $258-259$.

6. Saramak, D. Optimal production of electrolytic copper determined by the concentration and distribution of copper concentrates to smelters on the example of KGHM / D. Saramak // Archives of Metallurgy and Materials. - 2011. - Vol. 56, Issue 3. - PP. 619-626.

7. Программный комплекс для моделирования процесса выплавки коррозионностойких марок стали / Б.И. Леонович, В.В. Натальченко, Б.В. Ощепков, Е.А. Трофимов // Вестник ЮжноУральского государственного университета. Серия: Металлургия. - 2010. - № 13(189). - С. 19-23.

8. Применение электронных таблиц для расчета шихты при выплавке стали в ДСП фасоннолитейного цеха ОАО «Северсталь» / В.Л. Крохотин, Д.П. Михайлов, Л.М. Романов, А.Н. Болдин // Электрометаллургия. - 2003. - № 1. - С. 24-26.

9. Khaimovich, M.M. Automation of batch formula calculation / M.M. Khaimovich, K.Yu. Subbotin // Glass and Ceramics. - 2005. - Vol. 62, Issue 3. - PP. 109-112.

10. Михайлов, Д.П. Расчет шихты на единицу массы расплава заданного состава / Д.П. Михайлов, Л.М. Романов // Заготовительные производства в машиностроении. - 2007. - № 3. - С. 3-5.

11. A novel algorithm to scheduling optimization of melting-casting process in copper alloy strip production / X. Yan, Z. Zhang, J. Guo, etc. // Discrete Dynamics in Nature and Society. - 2015. - Vol. 2015. - 13 p.

12. Gill, P.E. Practical optimization / P.E. Gill, W. Murray, M.H. Wright. - Bingley: Emerald, 2008. - 401 p.

13. Sinha, S.M. Mathematical programming: Theory and methods / S.M. Sinha. - Delhi: Elsevier, 2006. - 572 p. 
14. Petrova, S.S. The origin of the method of steepest descent / S.S. Petrova, A.D. Solov'ev // Historia Mathematica. - 1997. - Vol. 24, Issue 4. - PP. 361-375.

\section{References}

1. Trauzeddel, D. (2014). Prozessorientierte Mittelfrequenzofentechnik. Giesserei Rundschau, 61(1/2), 16-21.

2. Marukovich, E.I., \& Karpenko, M.I. (2012). Casting Alloys and Technologies. Minsk: Belarus. Navuka.

3. Ertl, W., \& Dötsch, E. (2015). Melting of large steel casting parts in the induction furnace. Heat Processing, 2, 103-107.

4. Sezgtn, E. (2010). Efficiency of the melting technologies in furnaces of the company EGES Production. Foundry Production and Metallurgy, 3, 147-148.

5. Mizgir, A.G., \& Aladjev, .E. (2012). Modern process automation system for melting steel in induction furnaces and electric arc furnaces. Foundry Production and Metallurgy, 3, 258-259.

6. Saramak, D. (2011). Optimal production of electrolytic copper determined by the concentration and distribution of copper concentrates to smelters on the example of KGHM. Archives of Metallurgy and Materials, 56(3), 619-626. DOI:10.2478/v10172-011-0067-z

7. Leonovich, B.I., Natalchenko, V.V., Oschepkov, B.V., \& Trofimov, E.A. (2010). The program complex for modeling process of corrosion-resisting steels smelting. Bulletin of the South Ural State University: Metallurgy, 13, 19-23.

8. Krokhotin, V.L., Mikhailov, D.P., Romanov, L.M., \& Boldin, A.N. (2003). Application of spreadsheet tools for the calculation of charge during steel melting in EAF of steel foundry shop of JSC "Severstal". Elektrometallurgiya, 1, 24-26.

9. Khaimovich, M.M., \& Subbotin, K.Yu. (2005). Automation of batch formula calculation. Glass and Ceramics, 62(3), 109-112. DOI: 10.1007/s10717-005-0048-7

10. Mikhailov, D.P., \& Romanov, L.M. (2007). Calculation of charge a per unit melt weight of an ordered composition. Blanking Productions in Mechanical Engineering, 3, 3-5.

11. Yan, X. Zhang, Z., Guo, J., Li, S., \& Hu, K. (2015). A novel algorithm to scheduling optimization of melting-casting process in copper alloy strip production. Discrete Dynamics in Nature and Society, 2015, 147980. DOI:10.1155/2015/147980

12. Gill, P.E., Murray, W., \& Wright, M.H. (2008). Practical Optimization. Bingley: Emerald.

13. Sinha, S.M. (2006). Mathematical Programming: Theory and Methods. Delhi: Elsevier.

14. Petrova, S.S., \& Solov'ev, A.D. (1997). The origin of the method of steepest descent. Historia Mathematica, 24(4), 361-375. DOI:10.1006/hmat.1996.2146

Received December 23, 2016

Accepted March 7, 2017 